Arkadiusz Heder, Maria Tkocz

Uniwersytet Śląski, Katowice, Polska

\title{
Funkcjonowanie górnictwa węgla kamiennego w gospodarce opartej na wiedzy
}

\section{The Functioning of Coal Mining in a Knowledge-Based Economy}

Streszczenie: Górnictwo węgla kamiennego dzięki działaniom restrukturyzacyjnym stało się branżą osiągającą ostatnio dodatni wynik finansowy. Obecnie stoi przed wyzwaniem konkurencyjności na arenie międzynarodowej, zwłaszcza że Polska jest największym producentem węgla kamiennego w Unii Europejskiej, ale stanowi to zaledwie 1,1\% produkcji światowej (2011). Jedną z wielkich szans dla jego dalszego rozwoju jest wdrożenie zasad gospodarki opartej na wiedzy, polegającej na generowaniu innowacyjnych pomysłów, takich, które po wprowadzeniu przynoszą zyski materialne lub społeczne. Rozwój gospodarki opartej na wiedzy w tradycyjnej gałęzi przemysłu, jakim jest górnictwo węgla kamiennego jest odpowiedzią na wzrost konkurencji światowej i próbą dostosowania jej do wymagań rynku światowego. Wdrożenia GOW w górnictwie jest ważnym zadaniem z wielu względów. Po pierwsze przyczyni się do unowocześnienia procesu wydobycia, produkcji i organizacji a w związku z tym do obniżenia kosztów produkcji oraz utrzymania działalności przez współpracę z jednostkami naukowo-badawczymi, instytucjami otoczenia biznesu, organizacjami samorządowymi. Wprowadzenie nowoczesnych technologii doprowadzi również do poprawy stanu środowiska. Po drugie nastąpi przepływ kapitału ludzkiego czy przyciąganie nowych przedsiębiorstw, przez współpracę firm skupionych w branży górniczej - takie posunięcie wpłynie na skuteczniejsze zarządzanie i wymianę doświadczeń. Wszystkie te działania przyczynią się do stworzenia większej konkurencyjności na rynku międzynarodowym. Według definicji OECD gospodarka oparta na wiedzy (GOW) nakierowana jest na tworzenie, traktowane jako produkcja oraz dalsze przekazywanie, czyli dystrybucja oraz praktyczne wykorzystanie wiedzy i informacji.

Nasuwa się pytanie, czy przedstawione powyżej podstawy gospodarki opartej na wiedzy są wdrażane w górnictwie węgla kamiennego w Polsce? W pracy przedstawiono różnorodne formy współpracy z jednostkami naukowo-badawczymi oraz instytucjami otoczenia biznesu.

Abstract: Coal mining, due to its restructuring, has recently been achieving positive financial results. Currently, it is facing the challenge of international competitiveness, particularly because Poland is the largest coal producer in the European Union, which comprises only $1.1 \%$ of the world's production (2011). One of the great chances for its further development is the implementation of principles of a knowledge-based economy aimed at generating innovative ideas, which, once implemented, bring 
material or social profits. According to OECD's definition, a knowledge-based economy (KBE) is aimed at creating, understood as production, and further transmitting, that is distribution, as well as practical applications of knowledge and information. According to A. Kuklinski (2001), KBE is based on four basic pillars. The first pillar is education and training. The second pillar is information infrastructure. The third pillar is economic conditionings and institutional conditions, while the fourth are innovation systems.

The question that presents itself is whether the above rudiments of a knowledge-based economy are being implemented in coal mining in Poland. The article attempts to answer the question. It presents diversified forms of cooperation with academic and research units as well as business-related institutions.

Słowa kluczowe: górnictwo węgla kamiennego, gospodarka oparta na wiedzy innowacyjność, edukacja, klaster

Key words: coal mining, knowledge-based economy, innovation, education, cluster

\section{UWARUNKOWANIA GOSPODARKI OPARTEJ NA WIEDZY}

Kierunki przemian w gospodarce światowej, zachodzące w ostatnich latach, wskazują na przechodzenie od gospodarki industrialnej, opartej na ekonomii skali, do gospodarki wiedzochłonnej, związanej z potencjałem technologicznym i wysokim poziomem kapitału ludzkiego. Jak stwierdza Z. Zioło (2009) współczesne procesy rozwoju cywilizacyjnego zmierzające do kształtowania społeczeństwa informacyjnego sprawiają, że wiedza staje się coraz ważniejszym i cenniejszym dobrem, a W. Gierańczyk (2012) dodaje, że we współczesnej gospodarce podstawowym źródłem budowania przewagi konkurencyjnej jest kapitał ludzki, który staje się równoważny kapitałowi trwałemu. Znaczenie kapitału ludzkiego jako istotnego czynnika rozwoju gospodarki opartej na wiedzy podkreślali także m.in. Z. Chojnicki (2003), A. Świdurska (2009), Z. Zioło (2009, 2012), W. Kamińska (2011) i A. Szymańska (2011). Wiedza i innowacje są coraz bardziej uznawane za jeden z najważniejszych czynników decydujących o tempie i jakości wzrostu gospodarczego (Witkowska, Wysokińska 2006). Pojęcie „gospodarka oparta na wiedzy” (GOW) weszło na stałe do kanonu słownictwa ekonomicznego w latach 90. XX w. za sprawą takich uczonych, jak: K. Smith, P.F. Drucker, L. Thurow, A. Kukliński, B.A. Lundvall i B. Johnson (Dworak 2012). Pionierski wkład w powstanie koncepcji gospodarki opartej na wiedzy wniósł P.F. Drucker, który już w 1960 r. posługiwał się pojęciem ,praca oparta na wiedzy”. Określenie ,gospodarka oparta na wiedzy" stosowane jest zamiennie z takimi terminami, jak gospodarka informacyjna, gospodarka wiedzy, nowa gospodarka (Dworak 2012). Według definicji sformułowanej przez OECD i Bank Światowy GOW jest gospodarką, „w której wiedza jest tworzona, przyswajana, przekazywana i wykorzystywana bardziej efektywnie przez przedsiębiorstwa, organizacje, osoby fizyczne i społeczności, sprzyjając szybkiemu rozwojowi gospodarki i społeczeństwa" (OECD - Word Bank Institute 2000). Rozwój GOW jest głęboko uwarunkowanym holistycznym procesem ekonomicznym, społecznym, politycznym, naukowym i kulturowym. Głównymi podmiotami kreującymi rozwój GOW są: przedsiębiorstwa, społeczeństwo, władze publiczne i nauka (Kukliński 2005). W praktyce można wyróżnić kilka kluczowych 
czynników charakteryzujących proces użytkowania wiedzy: wykorzystanie osiągnięć nauki, techniki i technologii dla kreowania nowych produktów i usług, kreowanie warunków przyspieszających rozwój przedsiębiorczości, wyższe tempo wyszukiwania i wdrażania innowacji poprzez współpracę z naukowo-technicznym zapleczem gospodarki, skracanie cyklu życia produktu, rozwój edukacji w celu osiągnięcia wysokiego poziomu kwalifikacji przez pracowników oraz szybkie wdrożenie kształcenia ustawicznego, rozwój inwestycji w prace badawcze i rozwojowe w zakresie nowych produktów, technologii, know-how, systemy informatyczne, systemy organizacji i zarządzania oraz dystrybucję, jak również budowę łańcuchów sieci wartości. Wymienione czynniki były przedmiotem badań wielu autorów. M. Borowiec (2008), analizując kształcenie na poziomie akademickim, stwierdziła, że ośrodki szkolnictwa wyższego są podstawowymi ogniwami gospodarki opartej na wiedzy, warunkują poprawę zasobów kapitału ludzkiego oraz są źródłem innowacji. Potwierdza to Z. Chojnicki (2003) uznając, że z punku widzenia kształcenia gospodarka oparta na wiedzy ma stanowić gospodarkę ludzi uczących się. Istotny aspekt funkcjonowania GOW stanowią, nieliczne w Polsce, akademickie firmy spin-off. Ich problemy przedstawił P. Dawidko (2012), natomiast P. Wilczyński (2012) określił rolę rozwoju technologii wojskowych dla współczesnej innowacyjnej gospodarki. Problematyka innowacji w funkcjonowaniu przedsiębiorstw przemysłowych oraz ich roli w osiąganiu przewagi konkurencyjnej poprzez rozwój systemów organizacji i zarządzania była przedmiotem badań R. Repetowskiego (2008). Analizy przeprowadzone przez M. Borowiec, S. Dorockiego i B. Jennera (2009) wykazały jednoznacznie, że wysoka pozycja konkurencyjna niektórych państw wynika w dużym stopniu z ponoszonych wydatków na działalność $\mathrm{B}+\mathrm{R}$, z dobrze rozwiniętej współpracy pomiędzy nauką a przemysłem, z wysokiej jakości szkolnictwa wyższego i w konsekwencji kapitału ludzkiego oraz zdolności absorpcji nowych technologii, czyli podstawowych czynników decydujących o rozwoju gospodarki opartej na wiedzy. Na podstawie badań dotyczących światowych firm informatycznych W. Kilar (2009) zaproponowała interesujący wskaźnik zaawansowania rozwoju gospodarki opartej na wiedzy, za który uznała potencjał ekonomiczny firm w przestrzeni światowej. Przedstawione powyżej aspekty funkcjonowania gospodarki opartej na wiedzy stanowią podstawę rozwoju współczesnej cywilizacji informacyjnej.

\section{GÓRNICTWO WĘGLA KAMIENNEGO W GOSPODARCE OPARTEJ NA WIEDZY}

Przemiany zasad gospodarowania zasobami były jednym z głównych elementów transformacji polskiej gospodarki (Zioło, Rachwał 2008, 2009, 2012). Artykuł dotyczy gospodarki opartej na wiedzy, w bardzo specyficznej branży, jaką jest górnictwo węgla kamiennego. Wybór przedmiotu badań wynika m.in. stąd, że poza rolnictwem żaden segment polskiej gospodarki, nie przeszedł tak poważnych przemian (Tkocz 2006). Zapoczątkowany w latach 90. ubiegłego stulecia proces tworzenia gospodarki rynkowej wymagał szczególnie głębokich przemian w zakresie sposobu funkcjonowania i struktury tradycyjnych sektorów gospodarki, do których zalicza się m.in. górnictwo węgla kamiennego (Tkocz 2007; Melich-Iwanek 2010). Nasuwa się więc pytanie, czy podstawy gospodarki opartej na wiedzy są wdrażane 
w górnictwie węgla kamiennego w Polsce? Górnictwo węgla kamiennego przeszło wieloletni proces restrukturyzacji, przez zamknięcie wielu kopalń, systematyczny spadek wydobycia i zatrudnienia i zmiany własnościowe (Tkocz, Heder 2012). Dzięki działaniom restrukturyzacyjnym stało się branżą osiągającą ostatnio dodatni wynik finansowy. Obecnie górnictwo stoi przed wyzwaniem konkurencyjności na arenie międzynarodowej, zwłaszcza, że Polska jest największym producentem węgla kamiennego w Unii Europejskiej, ale stanowi to zaledwie 1,1\% produkcji światowej (2011). Jedną z wielkich szans dla jego dalszego rozwoju jest wdrożenie w jego funkcjonowaniu zasad gospodarki opartej na wiedzy, polegającej na generowaniu innowacyjnych pomysłów, które po wprowadzeniu przynoszą zyski materialne lub społeczne. Według definicji OECD gospodarka oparta na wiedzy (GOW) nakierowana jest na tworzenie, traktowane jako produkcja oraz dalsze przekazywanie, czyli dystrybucja oraz praktyczne wykorzystanie wiedzy i informacji. Zdaniem A. Kuklińskiego (2001) GOW bazuje na czterech podstawowych filarach: edukacja i szkolenia, infrastruktura informatyczna, uwarunkowania ekonomiczno-instytucjonalne, potencjał innowacyjności. Opierając się na przedstawionych założeniach, celem artykułu jest zaprezentowanie przykładów działań w górnictwie węgla kamiennego uwzględniających gospodarkę opartą na wiedzy. Materiał źródłowy stanowiły informacje uzyskane z Kompanii Węglowej oraz Jastrzębskiej Spółki Węglowej.

\section{ROZWÓJ EDUKACJI I SZKOLENIA}

Pierwszym filarem analizy jest edukacja i szkolenia oraz odpowiednie procesy kształcenia. Stanowią one główny przedmiot analizy oraz badań w obszarze GOW. Jest to związane z faktem, że wiedza i kompetencje pracowników decydują o innowacyjności i lepszej działalności przedsiębiorstwa. Wykształcenie i kwalifikacje są potrzebne do tego, aby tworzyć, przekazywać i wykorzystywać wiedzę. Dlatego ważnym elementem w procesie kształcenia jest odpowiedni system edukacji, adekwatny do nowych wymagań, skierowany na rynek i otoczenie, nie tylko na przyswajanie wiedzy teoretycznej (Borowiec 2008). W GOW od pracowników oczekuje się przede wszystkim kreatywności, kompetencji, interdyscyplinarności, zdolności do współpracy i umiejętności dopasowania się do zmian zachodzących na rynku (Olszak, Ziemba 2010).

W branży, jaką jest górnictwo węgla kamiennego, edukacja i szkolenia odgrywają ważną rolę w kontekście umiejętności wykorzystania wiedzy teoretycznej w praktycznej pracy. Mając na uwadze ważny czynnik, jakim jest bezpieczeństwo, istotnym elementem jest przygotowanie ludzi do bezpiecznej pracy oraz wyposażenie ich w niezbędną wiedzę na temat zagrożeń. Biorąc pod uwagę szybko następujące zmiany w sposobach zarządzania, innowacyjność w systemach informatycznych, stosowanie coraz nowocześniejszych maszyn górniczych we wszystkich etapach eksploatacji górniczej, transportu i przeróbki węgla, duże znaczenie ma edukacja pozaszkolna. Drugim czynnikiem wpływającym na wzrost popytu na usługi szkoleniowe jest rozpoczęty proces zmiany pokoleniowej w górnictwie węgla kamiennego, czyli odchodzenie z kopalń pracowników doświadczonych, z długim stażem 
pracy, a podejmowanie pracy przez osoby niedoświadczone, co wiązało się z faktem likwidacji w latach 90. XX wieku zawodowych szkół górniczych, które dopiero ostatnio zostały reaktywowane.

M. Majer oraz K. Nowak (2011) w ramach badań statutowych GIG przeprowadziły sondaż w zakładach górniczych (KW S.A., KHW S.A., JSW S.A., PKW S.A. i jednej samodzielnej kopalni) dotyczący oceny procesu ustawicznego kształcenia. W sondażu wzięło udział 26 przedstawicieli kopalń odpowiedzialnych za ustawiczne kształcenie zawodowe pracowników. Analizując wyniki sondażu, możliwości ustawicznego szkolenia zawodowego można uznać za dobre. Warto jednak zwrócić uwagę na wady systemu w procesie wyboru oraz podpisywaniu umów z zewnętrznymi placówkami szkoleniowymi przez spółki węglowe. Jak sygnalizują autorki sondażu, co czwarty badany zadeklarował, że kopalnia, którą reprezentuje nie ma możliwości wpływu na zakres programowy kursów świadczonych przez zewnętrzne ośrodki szkoleniowe. W aspekcie zróżnicowanych potrzeb szkoleniowych kopalń w ciągu najbliższych lat szczególny nacisk należy położyć na zabezpieczenie odpowiedniej wysokości środków finansowych dla poszczególnych kopalń (ryc. 1).

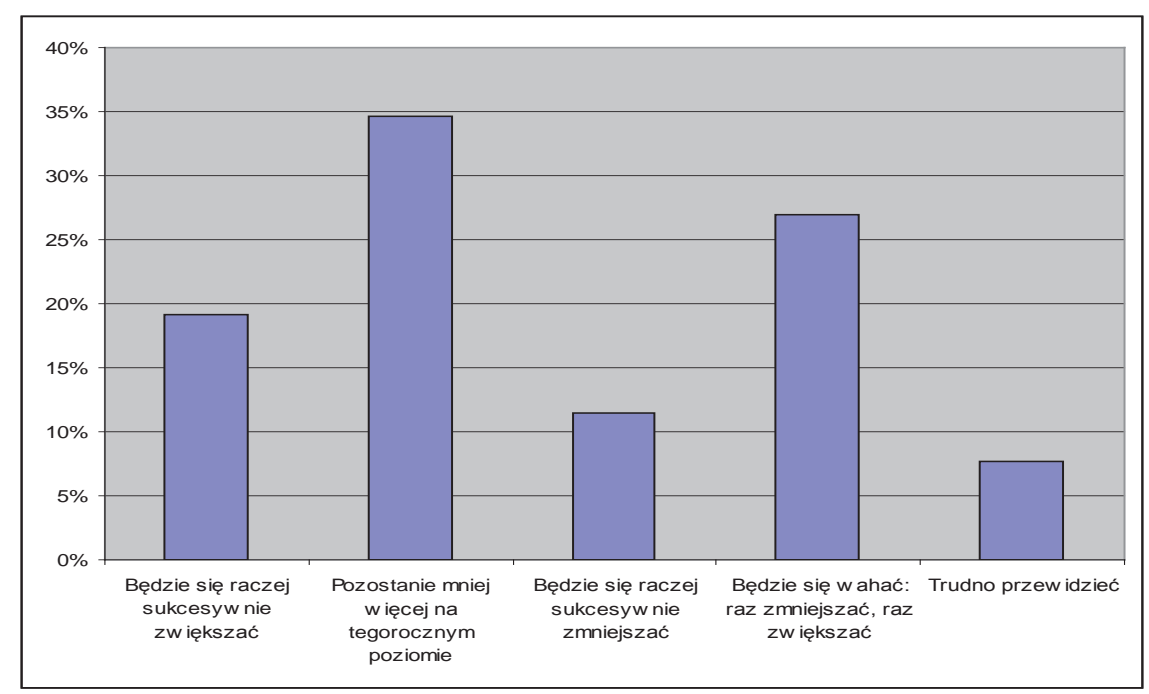

Ryc. 1. Skala potrzeb szkoleniowych w perspektywie trzech najbliższych lat oszacowana na podstawie liczby pracowników kopalń uczestniczących w procesie kształcenia ustawicznego.

Dane na podstawie sondażu przeprowadzonego w kopalniach

Źródło: Majer, Nowak 2011

Wychodząc naprzeciw oczekiwaniom dotyczącym szkoleń w 1996 roku powstała Spółka Szkoleniowa Sp. z o.o. w Katowicach. Spółka świadczy usługi szkoleniowe dla pracowników Katowickiego Holdingu Węglowego S.A. oraz przedsiębiorstw branży górniczej, pozwalające uzupełnić wiedzę ogólną, umiejętności i kwalifikacje zawodowe w formach pozaszkolnych. Spółka specjalizuje się w organizacji szkoleń BHP, kursów na stanowiska wymagające szczególnych kwalifikacji, kursów dla osób pracujących w oddziałach górniczych, 
szybowych, przewozu, przeróbki, elektrycznych oraz innych kursów niezbędnych w górnictwie (www.khw.pl).

Innym ważnym elementem rozwoju edukacji jest wszelkiego rodzaju współpraca uczelni wyższych oraz jednostek badawczych z przedsiębiorstwami górniczymi. Daje ona korzyści zarówno dla uczelni w postaci zdobycia doświadczenia praktycznego przez studentów i absolwentów, jak i dla przedsiębiorstw, przez wymianę doświadczeń z uczelniami w aspekcie teoretycznym (Dawidko 2012). Przykładem takiej współpracy jest podpisana w 2010 roku umowa między Akademią Górniczo-Hutniczą w Krakowie a Centrum Badań i Dozoru Górnictwa Podziemnego Sp. z o.o. Kierunki współdziałania polegają m.in. na uzgadnianiu tematów prac badawczych, prac magisterskich, wzajemnym prezentowaniu i propagowaniu osiągnięć czy współdziałaniu dotyczącym zatrudnienia absolwentów. Innym przykładem jest współpraca Politechniki Śląskiej z Powen-S.A. w zakresie konstrukcji i technologii pomp wirowych dla potrzeb górnictwa.

Pozytywnym przykładem wdrażania GOW w górnictwie w aspekcie edukacji jest wzrost poziomu wykształcenia wśród kadry pracowników kopalń (ryc. 2 i 3).

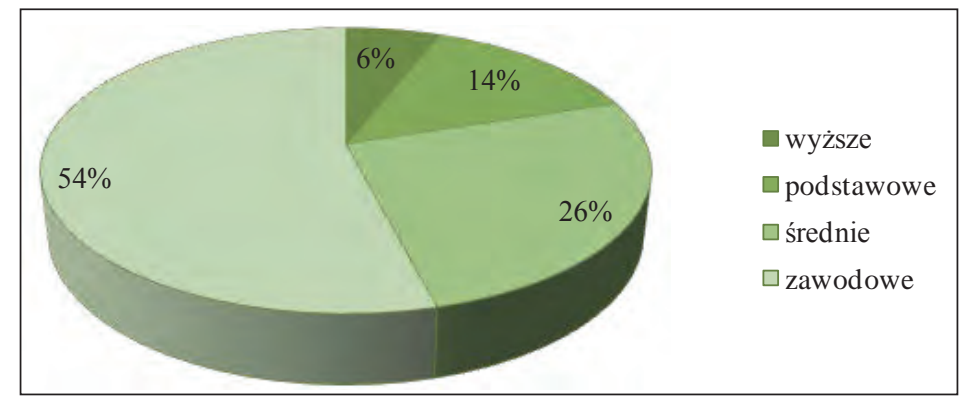

Ryc. 2. Wykształcenie pracowników JSW S.A. w 2005 roku

Źródło: opracowanie na podstawie danych z JSW S.A.

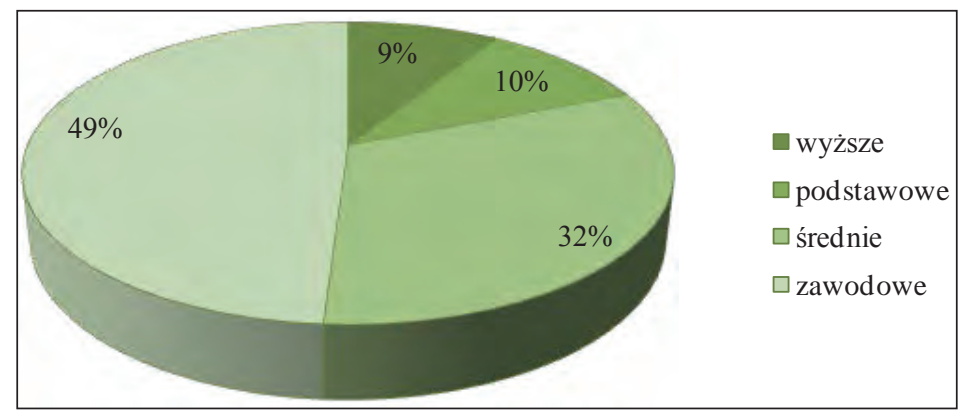

Ryc. 3. Wykształcenie pracowników JSW S.A. w 2008 roku

Źródło: opracowanie na podstawie danych z JSW S.A. 
ROZWÓJ I WYKORZYSTANIE TECHNOLOGII ORAZ INFRASTRUKTURY INFORMACYJNEJ

Drugim filarem jest infrastruktura informatyczna. Filar ten dotyczy szybkiej komunikacji i przekazywania informacji. System informacyjno-komunikacyjny tworzy kluczową infrastrukturę gospodarki opartej na wiedzy (Zioło 2009). Poprzez wspomaganie procesów związanych z warunkami udostępniania wiedzy można katalizować zdarzenia gospodarcze (Grudzewski, Hejduk 2004). W aspekcie infrastruktury informatycznej, gospodarka oparta na wiedzy jest szeroko wdrażana poprzez różnego rodzaju nowe systemy informatyczne dla poprawy jakości pracy kopalń, większej efektywności pracy, poprawy bezpieczeństwa. Przykładem może być wdrożenie systemu Asseco Safo ERP w kopalni węgla LW Bogdanka. Asseco Safo ERP wspiera procesy sprzedaży zarówno węgla grubego jak i miału oraz wywóz kamienia. System umożliwia generowanie dyspozycji do załadunku węgla na podstawie wystawionych dokumentów sprzedaży, zapewniając dokładną, zgodną z dokumentem realizację. Aplikacja prowadzi faktyczną ewidencję dokonanych operacji i naważek, umożliwia rozliczenie transakcji bilansując ilości zamówione i załadowane na samochód oraz generowanie raportów z dokonanego, rzeczywistego załadunku. Ponadto sprzedaż węgla znacznie usprawniono dzięki przypisaniu do kontrahentów wielu samochodów i kierowców (www. assecobs.pl). Innym przykładem jest system informatyczny wspierający zarządzanie zagrożeniami górniczymi. W Głównym Instytucie Górnictwa realizowano prace nad utworzeniem pionierskiego systemu. Do tej pory znane i stosowane systemy monitoringu zagrożeń, oceny ich stanów oraz systemy wspomagania zarządzania zagrożeniami nie umożliwiają wspólnej, syntetycznej oceny stanu zagrożeń górniczych oraz odpowiadającej jej oceny ryzyka zawodowego (www.wnp.pl).

\section{UWARUNKOWANIA EKONOMICZNO-INSTYTUCJONALNE}

Trzecim filarem są bodźce ekonomiczne i warunki instytucjonalne. Związane są ze swobodnym przepływem wiedzy, wspieraniem przedsiębiorczości i inwestycji w technologie komunikacyjne.

Postęp, jaki dokonał się w ostatnich latach w zrozumieniu problematyki konkurencyjności przedsiębiorstw, zarówno w aspekcie teoretycznym, jak i praktycznym, pozwolił na stworzenie systemowych rozwiązań dostosowanych do właściwości współczesnej gospodarki. Koncepcją, która w ostatnim czasie nabrała szczególnego znaczenia stała się polityka rozwoju oparta na klastrach. Koncepcja klastra stanowi nowy sposób myślenia o kreowaniu międzynarodowej konkurencyjności gospodarki (tab. 1). 
Tab. 1. Charakterystyka klastra

\begin{tabular}{|l|l|}
\hline \multicolumn{1}{|c|}{ Determinanty } & \multicolumn{1}{c|}{ Klastry } \\
\hline członkostwo & niewymagalne \\
\hline relacje, związki & kooperacja i konkurencja \\
\hline podstawy porozumienia & normy społeczne \\
\hline wartość dodana & korzyści zewnętrzne \\
\hline główne korzyści & $\begin{array}{l}\text { dostęp do dostawców, usług oraz rynku } \\
\text { pracy }\end{array}$ \\
\hline podstawy korzyści zewnętrznych & lokalizacja/bliskość \\
\hline wspólne cele & brak \\
\hline bliskość geograficzna & niezbędne \\
\hline
\end{tabular}

Źródło: Szultka 2004

Powstanie klastra niesie ze sobą korzyści zarówno dla gospodarki regionu (m.in. przez kształtowanie rynku wyspecjalizowanych czynników produkcji, stymulowanie przepływu wiedzy, tworzenie kultury innowacyjności i przedsiębiorczości w regionie, powstanie w regionie nowych podmiotów gospodarczych, zwiększenie atrakcyjności lokalizacyjnej dla bezpośrednich inwestycji zagranicznych), jak i dla przedsiębiorstw (m.in. wzrost produktywności dzięki dostępowi do wyspecjalizowanych czynników produkcji i redukcji kosztów dostępu do wspólnych zasobów, wzrost stopnia specjalizacji, możliwość podejmowania wspólnych działań marketingowych) (Brodzicki, Tamowicz 2008). Klastry powstają praktycznie we wszystkich sektorach gospodarki. Występują zarówno w przemyśle, jak i w usługach, w sektorach wysokich technologii, jak i w tradycyjnych. Charakteryzują się również różnym poziomem innowacyjności i zaawansowania technologicznego, a tym samym różnymi strategiami i perspektywami rozwoju (Brodzicki, Szultka 2002). W badanej branży, jaką jest górnictwo węgla kamiennego, można scharakteryzować trzy klastry. Pierwszym z nich jest Klaster Maszyn Górniczych, którego działalność rozpoczęła się w 2011 roku. Klaster tworzą: instytucja zaplecza naukowego (Instytut Techniki Górniczej Komag, który był inicjatorem utworzenia klastra), przedsiębiorcy (Zabrzańskie Zakłady Mechaniczne S.A., Damel S.A., Elsta Sp. z o.o., Edjan Jednostka Innowacyjno-Wdrożeniowa, Elhand Transformatory Sp. z o.o., Timler Zakłady Elektrotechniki Budowlanej i Przemysłowej, Ponar-Silesia S.A.) oraz instytucja otoczenia biznesu (Górnicza Izba Przemysłowo-Handlowa). Członkowie Założyciele za cel utworzenia klastra stawiają sobie ,uzyskanie możliwości produkcyjnych nowych jakościowo, konkurencyjnych na rynku krajowym oraz rynkach światowych, innowacyjnych, bezpiecznych rozwiązań maszyn górniczych powstałych w wyniku aktywnej współpracy uczestników klastra”. Klaster ma formułę otwartą i będzie zabiegał o przystępowanie nowych członków, zarówno z grupy przedsiębiorców, jak i instytucji naukowych, instytucji otoczenia biznesu czy władz regionalnych (www.klastermg.eu). Funkcjonowanie kolejnego opisywanego klastra, czyli Innowacyjnego Śląskiego Klastra Czystych Technologii Węglowych oparte jest na publiczno-prywatnym partnerstwie trzech grup podmiotów: nauki, przemysłu i samorządów. Członkami założycielami Klastra, którzy w 2005 roku podpisali umowę partnerską są: Główny Instytut Górnictwa, Politechnika Śląska, Instytut Chemicznej Przeróbki Węgla, 
Instytut Inżynierii Chemicznej PAN, Południowy Koncern Energetyczny S.A., Kompania Węglowa S.A., Jastrzębska Spółka Węglowa S.A., Katowicki Holding Węglowy S.A., oraz miasta Gliwice, Jastrzębie Zdrój, Jaworzno, Katowice, Rybnik, Tychy. Obecnie do klastra należy 30 podmiotów. Obszar działania klastra obejmuje trzy główne grupy tematyczne: bezpieczne i ekonomiczne wydobywanie węgla oraz przygotowanie węgli ultra czystych dla celów energetyki w aspekcie nowych rozwiązań technologicznych wytwarzania finalnych nośników energii, systemy konwersji węgla w użyteczne nośniki energii, oraz ograniczanie emisji substancji szkodliwych (w tym dwutlenku węgla) w procesach użytkowania węgla. Cel nadrzędny klastra to stworzenie Śląskiej Doliny Czystych Technologii Węglowych stanowiącej dla Polski szansę dla realizacji zrównoważonego rozwoju i zapewnienia bezpieczeństwa energetycznego (www.coal.silesia.pl). Trzecim klastrem związanym z górnictwem jest Śląski Klaster Rewitalizacji i Technologii Środowiskowych. Tworzy go sektor naukowy (Główny Instytut Górnictwa, Instytut Ekologii Terenów Uprzemysłowionych, Politechnika Śląska i Wyższa Szkoła Biznesu w Dąbrowie Górniczej), sektor małych i średnich przedsiębiorstw (m.in. Aerdo Group, Centrum Projektów Rewitalizacji S.A., Haldex S.A., Centrum Badań i Dozoru Górnictwa Podziemnego Sp. z o.o.), oraz sektor instytucji otoczenia biznesu (m.in. Firma Optirem Sp. z o.o., Izba Gospodarcza Piekary Śląskie). Celem działalności klastra jest m.in. stworzenie sieci współpracy w obszarze wymiany doświadczeń w zakresie procesów rewitalizacyjnych i innowacyjnych technologii środowiskowych, wspieranie przedsiębiorczości w obszarze innowacyjnych technologii rewitalizacyjnych i środowiskowych (www.revitaklaster.pl).

\section{WZROST POTENCJAŁU INNOWACYJNOŚCI}

Czwarty filar to systemy innowacji. Ośrodki badawcze, uniwersytety, centra badawcze, zespoły eksperckie, partnerstwo publiczno-prywatne są niezbędne do wykorzystania zasobów wiedzy oraz tworzenia nowej wiedzy. Filar ten zajmuje szczególne miejsce wśród czynników warunkujących konkurencyjność. Wdrażanie wiedzy w praktycznym działaniu staje się głównym czynnikiem konkurencyjności. Duże znaczenie ma stworzenie systemu, który zachęcałby do efektywnego wykorzystania istniejącej wiedzy, kreowania nowej wiedzy i podejmowania nowych działalności. Jest to w pewnym sensie podstawa do budowy efektywnego systemu innowacji, obejmującego firmy, naukę, ośrodki badawcze, uniwersytety, firmy konsultingowe i inne organizacje, które współdziałając mogą sięgać do zasobów wiedzy globalnej, adaptować tę wiedzę do potrzeb lokalnych i wykorzystywać ją do tworzenia nowej wiedzy oraz technologii (Chojnicki 2003; Kukliński 2001; Zioło 2012). Przykładami działań, jakie można zaobserwować w zakresie wdrażania wiedzy w praktycznym działaniu są Centra Innowacji i Transferu Technologii przy Politechnice Śląskiej oraz przy Akademii Górniczo-Hutniczej. Centrum Innowacji i Transferu Technologii Politechniki Śląskiej powstało w odpowiedzi na potrzebę stworzenia jednostki służącej promocji współpracy nauki, biznesu i samorządu. Fundamentalnym założeniem aktywności rynkowej Centrum jest takie ukierunkowanie kapitału intelektualnego Politechniki Śląskiej, aby uczelnia mogła być 
znaczącym ośrodkiem transferu wiedzy i rozwoju innowacji. Wzrost innowacyjności jest obecnie kluczowym czynnikiem wpływającym na rozwój gospodarczy Polski. Stąd potrzeba tworzenia jednostek wspierających działania w tym kierunku. Głównym celem funkcjonowania Centrum Innowacji i Transferu Technologii jest łączenie nauki i biznesu (www.citt. polsl.pl).

Narodowe Centrum Badań i Rozwoju w ramach swoich strategicznych programów finansuje zadania badawcze współrealizowane przez AGH. Zadanie badawcze nr 3 pt.: „Opracowanie technologii zgazowania węgla dla wysokoefektywnej produkcji paliw i energii elektrycznej" realizowane jest w ramach strategicznego programu badań naukowych i prac rozwojowych pt.: „Zaawansowane technologie pozyskiwania energii przez Konsorcjum Zgazowanie Węgla", którego liderem jest AGH w Krakowie, a w jego skład wchodzą partnerzy naukowi: Główny Instytut Górnictwa w Katowicach, Instytut Chemicznej Przeróbki Węgla w Zabrzu, Politechnika Śląska w Gliwicach oraz partnerzy przemysłowi: Katowicki Holding Węglowy S.A., KGHM Polska Miedź S.A., Tauron Polska Energia S.A., Południowy Koncern Energetyczny S.A., Południowy Koncern Węglowy S.A. oraz ZAK S.A. Podstawowym celem zadania badawczego jest określenie priorytetowych kierunków rozwoju technologii węglowych, co winno umożliwić opracowanie racjonalnej polityki oraz podjęcie strategicznych decyzji dotyczących rozwoju czystych, węglowych technologii energetycznych, dywersyfikacji bazy surowcowej dla przemysłu chemicznego oraz zwiększenia bezpieczeństwa energetycznego kraju poprzez wykorzystanie produktów powstających w procesach zgazowania węgla. Zadanie badawcze, rozpoczęte w 2010 roku, realizowane będzie do 2015 roku. Finansowanie obejmuje środki z Narodowego Centrum Badań i Rozwoju, które wynoszą $80 \mathrm{mln}$ złotych oraz wkład partnerów przemysłowych w wysokości ok. 9,8 mln złotych (www.zgazowaniewegla.agh.edu.pl).

Ciekawym przykładem działań innowacyjnych jest stworzenie na terenie byłej KWK „Niwka-Modrzejów” w Sosnowcu Parku Naukowo-Technicznego. Projekt obejmuje m.in. adaptację poprzemysłowego budynku dawnego centrum zarządzania kopalni na potrzeby obiektu produkcyjno-laboratoryjnego. Projekt stanowi odpowiedź na potrzeby regionu, miasta oraz przedsiębiorców, którzy działają i planują działać w dziedzinie innowacji. Celem projektu jest m.in. budowa i rozwój infrastruktury wspierającej powstanie i rozwój małych, innowacyjnych firm, transfer technologii do firm, dywersyfikacja i unowocześnianie struktury gospodarki miasta (materiały miasta Sosnowiec).

Istotne znaczenie z punktu widzenia konkurencyjności górnictwa węgla kamiennego ma także inwestowanie w bardziej wydajne technologie i rozwiązania, jak np. odmetanowanie przedeksploatacyjne (czyli prowadzone jeszcze zanim rozpocznie się wydobycie węgla $\mathrm{z}$ danego pokładu), opracowanie nowych technologii spalania, produkcja ekologicznych sortymentów węgla o wysokiej jakości, nowe technologie przerobu węgla na paliwa płynne. Przykładem tych inwestycji jest zagospodarowanie metanu z kopalni Staszic, który posłuży do produkcji prądu i ciepła. Rocznie z wyrobisk tej kopalni, należącej do Katowickiego Holdingu Węglowego, ze złóż węgla wydziela się ok. 5-6 mln $\mathrm{m}^{3}$ metanu. Ponad 70\% gazu trafia do atmosfery drogą wentylacyjną. Pozostała część jest ujmowana do instalacji odmetanowania. W przeszłości nabywcą tego gazu była pobliska huta, wykorzystująca go 
w procesach technologicznych; gdy zrezygnowała, niewykorzystany metan wypuszczano w powietrze. Przedstawiciele KHW podkreślają, że dzięki temu przedsięwzięciu metan zmieni się w użyteczny i atrakcyjny towar. Zastosowanie czystszego od węgla paliwa oznacza również znacznie mniej szkodliwych pyłów i gazów w powietrzu (www.gornictwo.wnp.pl).

\section{Podsumowanie}

W artykule zaprezentowano przykłady stosowania gospodarki opartej na wiedzy w górnictwie węgla kamiennego, nawiązujące do przedstawionej na wstępie koncepcji czterech filarów Kuklińskiego (2001). Syntetyczne ujęcie tych koncepcji zawarto w tabeli 2.

Tab. 2. Górnictwo węgla kamiennego w gospodarce opartej na wiedzy

\begin{tabular}{|l|l|}
\hline \multicolumn{1}{|c|}{$\begin{array}{c}\text { Filary gospodarki } \\
\text { opartej na wiedzy }\end{array}$} & \multicolumn{1}{c|}{$\begin{array}{c}\text { Przykłady w górnictwie } \\
\text { węgla kamiennego }\end{array}$} \\
\hline Rozwój edukacji i szkolenia & $\begin{array}{l}\text { - Spółki szkoleniowe } \\
\text { - Współpraca uczelni z jednostkami badawczymi i przed- } \\
\text { siębiorstwami }\end{array}$ \\
\hline $\begin{array}{l}\text { Rozwój i wykorzystanie technologii } \\
\text { oraz infrastruktury informacyjnej }\end{array}$ & $\begin{array}{l}\text { Wdrożenia nowych systemów informatycznych dla popra- } \\
\text { wy funkcjonowania kopalń }\end{array}$ \\
\hline $\begin{array}{l}\text { Uwarunkowania ekonomiczno- } \\
\text {-instytucjonalne }\end{array}$ & $\begin{array}{l}\text { - Klastry: Maszyn Górniczych, Innowacyjny Śląski } \\
\text { Klaster Czystych Technologii Węglowych, Śląski Klaster } \\
\text { Rewitalizacji i Technologii Srodowiskowych }\end{array}$ \\
\hline Wzrost potencjału innowacyjności & $\begin{array}{l}\text { - Centra Innowacji i Transferu Technologii } \\
\text { - Narodowe Centrum Badań i Rozwoju } \\
\text { - Park Naukowo-Techniczny }\end{array}$ \\
\hline
\end{tabular}

Źródło: opracowanie własne

Stwierdzono podejmowanie różnorodnych pozytywnych działań w aspekcie gospodarki opartej na wiedzy, jednak górnictwo ma również swoje problemy do rozwiązania, które utrudniają pełny rozwój GOW w branży górniczej. Należy do nich m.in.:

- konieczność uwzględniania zmienności warunków geologicznych oraz występowania zagrożeń naturalnych,

- ograniczone środki finansowe, jakimi dysponują polskie kopalnie, które nie pozwalają na uruchomienie i prowadzenie własnych badań,

- bardzo duże nakłady finansowe, które spółki muszą ponieść na zakup nowoczesnego sprzętu oraz innowacyjne rozwiązania,

- brak specjalistycznej kadry. Niejednokrotnie wśród pracowników kopalń brakuje osób wykształconych i przeszkolonych do prowadzenia badań laboratoryjnych jak też naukowych. Wobec takiej sytuacji, jedyną możliwością pozyskania wiedzy i dostępu do nowoczesnych technologii jest współpraca kopalń z zewnętrznymi ośrodkami badawczymi, które zwykle są publicznymi ośrodkami naukowymi. Skala prowadzonych badań często wykracza 
poza możliwości jednej jednostki, w związku z czym tworzone są konsorcja, w skład których wchodzi kilka ośrodków naukowo-badawczych (Napieraj, Sukiennik 2012).

Zagrożeniem dla wdrażania procesów innowacyjnych są ograniczenia finansowe. Jak piszą Turek, Jonek-Kowalska i Ganszczyk (2011: 165): „Wysokie koszty wydobycia węgla kamiennego oraz niekorzystne relacje cen tego surowca na rynkach światowych spowodowały w kilku ostatnich latach znaczne pogorszenie rentowności przedsiębiorstw górniczych”. Ważne znaczenie dla sytuacji finansowej ma również zaplecze materiałowo-techniczne przedsiębiorstw górniczych, które wymagają w wielu kopalniach modernizacji lub wymiany. Wprowadzenie innowacji zostanie osiągnięte po dekapitalizowaniu przedsiębiorstwa, drogą poprawy sytuacji finansowej spółek węglowych (Turek, Jonek-Kowalska, Ganszczyk 2011). Wprowadzanie innowacyjności w górnictwie odbywa się poprzez automatyzację i komputeryzację procesów technologicznych. Duże znaczenie w procesach zarządzanych mają programy wspomagające zarządzanie przedsiębiorstwem. Należy podkreślić również duże bariery we wdrażaniu innowacyjności produktowych, ze względu na uwarunkowania naturalne i geologiczno-górnicze (Turek, Jonek-Kowalska, Ganszczyk 2011).

Dane Głównego Urzędu Statystycznego na temat poziomu innowacyjności polskich przedsiębiorstw pokazują, że górnictwo charakteryzuje najniższy poziom innowacyjności, co dowodzi niskiej innowacyjności branż tradycyjnych (tab. 3).

Tab. 3. Udział górnictwa w kreowaniu innowacji w latach 2006-2008 (przedsiębiorstwa, które wprowadziły innowacje w \% ogółu przedsiębiorstw)

\begin{tabular}{|l|c|c|c|}
\hline \multirow{2}{*}{\multicolumn{1}{|c|}{ Wyszczególnienie }} & \multicolumn{3}{c|}{ Liczba zatrudnionych } \\
\cline { 2 - 4 } & $10-49$ & $50-249$ & powyżej 249 \\
\hline Ogółem przemysł & 14,6 & 32,7 & 60,7 \\
\hline Górnictwo & 9,6 & 24,3 & 46,9 \\
\hline Przetwórstwo przemysłowe & 14,7 & 33,0 & 60,7 \\
\hline $\begin{array}{l}\text { Wytwarzanie i zaopatrywanie } \\
\text { w energię elektryczną, gaz, wodę }\end{array}$ & 11,3 & 30,3 & 63,4 \\
\hline Ogółem sektor usług & 12,5 & 25,0 & 47,7 \\
\hline
\end{tabular}

Źródło: Turek i in. (2011) na podstawie sprawozdania GUS: Działalność innowacyjna przedsiębiorstw w latach 2006-2008, Warszawa 2009

Innowacyjność w górnictwie to głównie działania związane z ulepszeniem procesu technologicznego oraz organizacyjnego. Niskim poziomem innowacji charakteryzują się natomiast innowacje ukierunkowane dla rynku (Turek, Jonek-Kowalska, Ganszczyk 2011).

Zarządzanie wiedzą w przedsiębiorstwach górniczych ma duże znaczenie ze względu na specyfikę ich funkcjonowania, skomplikowaną strukturę złożoną z elementów powiązanych licznymi uwarunkowaniami i relacjami organizacyjnymi, ekonomicznymi, finansowymi, technicznymi i technologicznymi. W tym celu należy zapewnić odpowiedni poziom wykwalifikowania pracowników jak i odpowiedni rozwój techniczny przedsiębiorstwa. Działania związane z „wiedzą” są wdrażane w górnictwie i dają wymierne efekty. Przykładem jest zastosowanie metod i modeli matematycznych w praktyce zarządzania produkcją górniczą 
dzięki rozwojowi technik komputerowych. Rozwój technologii pozwala na rejestrowanie dużych zasobów informacji i danych o realizowanym procesie wydobywczym, stanowiącym zasób wiedzy, które można wykorzystać do poprawy jakości procesu projektowania przyszłej produkcji górniczej (Magda, Franik 2011).

Podsumowując, można stwierdzić, że działania innowacyjne i związane z wiedzą są realizowane w górnictwie węgla kamiennego, jednak w niewystarczającym stopniu, głównie ze względu na bardzo duże koszty produkcji niewspółmierne do poziomu kapitału finansowego przeznaczanego na tę branżę, oraz wpływ uwarunkowań naturalnych. Jednak wiele działań jest podejmowanych i w ostatnich latach w dziedzinie innowacji i wiedzy nastąpił postęp, m.in. dzięki wdrażaniu nowych systemów informatycznych, rozwojowi współpracy spółek węglowych z jednostkami naukowo-badawczymi czy zmianom organizacyjnym, polegającym na poszerzaniu współpracy w ramach klastrów. Mimo tych działań można stwierdzić, że górnictwo węgla kamiennego znajduje się w początkowej fazie wprowadzania gospodarki opartej na wiedzy.

\section{Literatura / References}

Borowiec, M. (2008). Kształcenie na poziomie akademickim jako czynnik przygotowania kadr dla przemysłu województwa podkarpackiego. Prace Komisji Geografii Przemystu Polskiego Towarzystwa Geograficznego, 10, 245-266.

Borowiec, M., Dorocki, S., Jenner, B. (2009). Wpływ zasobów kapitału ludzkiego na kształtowanie społeczeństwa informacyjnego i innowacyjność struktur przemysłowych. Prace Komisji Geografii Przemystu Polskiego Towarzystwa Geograficznego, 13, 95-121.

Brodzicki, T., Szultka, S. (2002). Koncepcja klastrów a konkurencyjność przedsiębiorstw. Organizacja i Kierowanie, 4(110), 1-14.

Chojnicki, Z. (2003). Polska na ścieżce rozwoju gospodarki opartej na wiedzy. Podejście regionalne. Przegląd Geograficzny, 74, 1, 23-39.

Dawidko, P. (2012). Biotechnologiczne spółki spin-off Uniwersytetu Jagiellońskiego jako mechanizm transferu technologii. Prace Komisji Geografii Przemystu Polskiego Towarzystwa Geograficznego, 20, 95-107.

Dworak, E. (2012). Gospodarka oparta na wiedzy w Polsce. Łódź: Wydawnictwo Uniwersytetu Łódzkiego.

Gierańczyk, W. (2012). Kapitał ludzki w przemyśle jako źródło przewagi konkurencyjnej w państwach Unii Europejskiej. Prace Komisji Geografii Przemystu Polskiego Towarzystwa Geograficznego, $19,28-44$.

Grudzewski, W., Hejduk, I. (2004). Zarządzanie wiedza w przedsiębiorstwach. Warszawa: Difin.

Kamińska, W. (2011). Kapitał ludzki i społeczny na obszarach wiejskich w Polsce. Przykład województwa świętokrzyskiego. Kielce: Instytut Geografii Uniwersytetu Humanistyczno-Przyrodniczego Jana Kochanowskiego.

Kilar, W. (2009). Koncentracja przestrzenna światowych firm informatycznych. Prace Komisji Geografii Przemystu Polskiego Towarzystwa Geograficznego, 12, 97-108.

Kukliński, A. (red.) (2001). Gospodarka oparta na wiedzy: wyzwanie dla Polski XXI wieku. Warszawa: Komitet Badań Naukowych. 
Magda, R., Franik, T. (2011). Komputerowo zintegrowane zarzadzanie. Wybrane aspekty zarzadzania wiedza $w$ procesie projektowania parametrów pól eksploatacyjnych $w$ kopalniach węgla kamiennego. Komputerowo zintegrowane zarządzanie, t. 2. Opole: Oficyna Wydawnicza Polskiego Towarzystwa Zarządzania Produkcją.

Majer, M., Nowak, K. (2011). Rynek edukacji pozaszkolnej dla górnictwa węgla kamiennego - opinie odbiorców usług. Górnictwo i Środowisko, Prace Naukowe GIG, 3, 61-72.

Melich-Iwanek, K. (2010). Gospodarka zasobami ludzkimi w górnictwie węgla kamiennego - studium ekonometryczno-statystyczne. Katowice: Wydawnictwo Uniwersytetu Ekonomicznego.

Napieraj, A., Sukiennik, M. (2012). Zarządzanie wiedzą w aspekcie tworzenia zintegrowanych systemów zarządzania przedsiębiorstwem górniczym. W: R. Knosal (red.), Innowacje w zarządzaniu i inżynierii produkcji. Opole: Oficyna Wydawnicza Polskiego Towarzystwa, 536-547.

Olszak, M., Ziemba, E. (red.) (2010). Kierunki rozwoju społeczeństwa informacyjnego i gospodarki opartej na wiedzy w świetle ślaskich uwarunkowań regionalnych. Katowice: Wydawnictwo Uniwersytetu Ekonomicznego.

Porter, M.E. (2001). Porter o konkurencji. Warszawa: PWE.

Repetowski, R. (2008). Rola innowacji w funkcjonowaniu przedsiębiorstw przemysłowych. Prace Komisji Geografii Przemystu Polskiego Towarzystwa Geograficznego, 10, 173-187.

Świdurska, A. (2009). Kształtowanie się przemysłu wysokiej techniki w Polsce. Prace Komisji Geografii Przemystu Polskiego Towarzystwa Geograficznego, 13, 56-67.

Szultka, S. (2004). Klastry. Innowacyjne wyzwanie dla Polski. Gdańsk: Instytut Badań nad Gospodarką Rynkową.

Szymańska, A.I. (2011). Implementacja systemu TQM w podnoszeniu pozycji konkurencyjnej przedsiębiorstwa przemysłowego. Prace Komisji Geografii Przemystu Polskiego Towarzystwa Geograficznego, 17, 243-260.

Tkocz, M. (2006). Efekty restrukturyzacji górnictwa węgla kamiennego w Polsce. Prace Komisji Geografii Przemystu Polskiego Towarzystwa Geograficznego, 9, 9-28.

Tkocz, M. (2007). Zmiany funkcjonowania górnictwa węgla kamiennego w Polsce po roku 1989. Acta Geographia Silesiana, WNoZ UŚ, 2, 51-58.

Tkocz, M., Heder, A. (2012). Działalność innowacyjna upadającej branży przemysłowej na przykładzie górnictwa węgla kamiennego. Prace Komisji Geografii Przemystu Polskiego Towarzystwa Geograficznego, 20, 243-260.

Turek, M., Jonek-Kowalska, I., Ganszczyk, Z. (2011). Determinanty innowacyjności w przedsiębiorstwach górniczych. Zeszyty Naukowe. Organizacja i Zarządzanie, Politechnika Śląska, 55, 159-172.

Wilczyński, P. (2012). Innowacje w zbrojeniach i obronności jako katalizator przemian technologicznych. Prace Komisji Geografii Przemystu Polskiego Towarzystwa Geograficznego, 12, 124-133.

Witkowska, J., Wysokińska, Z. (2006). Umiędzynarodowienie matych i średnich przedsiębiorstw a proces integracji europejskiej. Aspekty teoretyczne i empiryczne. Łódź: Wydawnictwo Uniwersytetu Łódzkiego.

Zioło, Z. (2009). Rola przemysłu w procesie kształtowania społeczeństwa informacyjnego. Prace Komisji Geografii Przemystu Polskiego Towarzystwa Geograficznego, 13, 11-20.

Zioło, Z. (2012). Miejsce innowacyjności w kształtowaniu procesów rozwoju gospodarczego układów przestrzennych. Prace Komisji Geografii Przemystu Polskiego Towarzystwa Geograficznego, 20, 9-32. 
Zioło, Z., Rachwał, T. (red.) (2008). Procesy transformacji układów przestrzennych przemystu na tle zmieniającego się otoczenia. Kraków: Wydawnictwo Naukowe UP.

Zioło, Z., Rachwał, T. (red.) (2009). Funkcje przemystu w kształtowaniu społeczeństwa informacyjnego. Kraków: Wydawnictwo Naukowe UP.

Zioło, Z., Rachwał, T. (red.) (2012). Wpływ innowacyjności na zmiany gospodarki w układach przestrzennych. Kraków: Wydawnictwo Naukowe UP.

\section{Strony internetowe}

Brodzicki, T., Tamowicz, P. (2008). Propozycja instrumentu stużacego zwiększeniu stopnia transferu wiedzy i technologii w ramach inicjatyw klajstrowych. Opracowanie na zlecenie Instytutu Technologii Eksploatacji, Gdańsk-Radom, 3-13. Pozyskano z: http://www.mg.gov.pl/NR/rdonlyres/79426B48-A8A9-4865-B28E-996FB30BBE39/52828/Ekspertyzainstrumentklastry.pdf.

Kukliński, A. (2005). Gospodarka oparta na wiedzy (G.O.W.) jak nowy paradygmat trwatego rozwoju (materiat z konferencji). Warszawa-Nowy Sącz, 1-16. Pozyskano z: http://www.instytut.info/ images/stories/konferencje/01_seminarium/Kuklinski.pdf.

OECD - Word Bank Institute Document. (2000). Korea and the Knowledge-Based Economy. Making the Transition. Paris. Pozyskano z: http://www.wds.worldbank.org/servlet/WDSContentServer/ WDSP/IB/2000/08/14/000094946_0007210532051/Rendered/PDF/multi_page.pdf.

Centrum Innowacji i Transferu Technologii Politechniki Śląskiej (CITT). (2012, 20 grudnia). Pozyskano z: http://www.citt.polsl.pl/O_nas.

Innowacyjny Śląski Klaster Czystych Technologii Węglowych. (2012, 17 grudnia). Pozyskano z: $\mathrm{http}$ ://coal.silesia.pl/index.php?option=com_content\&task=view\&id=12\&Itemid=27.

Katowicki Holding Węglowy. (2012, 29 grudnia). Spółka szkoleniowa Spółka z. o.o Pozyskano z: http://www.khw.pl/?d=211.

Konsorcjum Naukowo-Przemysłowe „Zgazowanie Wegla”. (2012, 15 grudnia). Pozyskano z: http:// www.zgazowaniewegla.agh.edu.pl/index.php?option $=$ com_content\&view $=$ article\&id $=109 \&$ Itemid $=50 \&$ lang $=$ pl.

Malec, M. (2012, 16 grudnia). Powstanie klastra maszyn górniczych. Pozyskano z: http://www.klastermg.eu/.

PAP, wnp.pl portal gospodarczy. (2012, 7 sierpnia). Pozyskano z: http://gornictwo.wnp.pl/metan-z-kopalni-staszic-posluzy-do-produkcji-pradu-i-ciepla,176070_1_0_0.html.

Śląski Klaster Rewitalizacji i Technologii Środowiskowych. (2012, 14 grudnia). Pozyskano z: http:// www.revitaklaster.pl/tasks, $9 . \mathrm{html}$.

Wdrożenie Asseco Safo ERP w kopalni węgla LW Bogdanka. (2012, 15 grudnia). Pozyskano z: http:// www.assecobs.pl/en/references/case-studies/wdrozenie-asseco-safo-erp-w-kopalni-wegla-lw-bogdanka.

Zintegrowany system zarządzania zagrożeniami w kopalniach - koncepcja rozwiązania. (2012, 16 grudnia). Pozyskano z: http://www.wnp.pl/artykuly/zintegrowany-system-zarzadzania-zagrozeniami-w-kopalniach-koncepcja-rozwiazania,4417_0_0_3_0.html.

\section{Inne materiały}

Materiały informacyjne miasta Sosnowiec 
Maria Tkocz, dr hab., profesor nadzwyczajny Uniwersytetu Śląskiego, Wydział Nauk o Ziemi.

Doktor habilitowany Nauk o Ziemi w zakresie geografii, profesor nadzwyczajny Uniwersytetu Śląskiego, kierownik Zakładu Gospodarki Przestrzennej. Specjalizuje się w zakresie geografii ekonomicznej, zwłaszcza geografii przemysłu, miast, turystyki oraz gospodarki przestrzennej. Jest autorem ponad 100 publikacji, w tym czterech monografii.

Maria Tkocz, Assistant Professor of Earth Sciences in the field of Geography, Associate Professor at the University of Silesia, Head of the Department of Spatial Planning. She specializes in economic geography, especially industrial, city, tourism, and spatial planning. Maria Tkocz is the author of over 100 publications, including four monographs.

Arkadiusz Heder, mgr geografii, doktorant w Katedrze Geografii Ekonomicznej Uniwersytetu Śląskiego. Jego zainteresowania dotyczą gospodarki przestrzennej, rozwoju lokalnego i regionalnego miast oraz przemian funkcjonalnych w miastach górniczych.

Arkadiusz Heder, MA in Geography. Geography PhD student in the Department of Economic Geography at the University of Silesia. His interests include spatial planning, local and regional development of cities and functional transformations in mining cities.

adres/address: Uniwersytet Śląski

ul. Bankowa 12, 40-007 Katowice, Polska

e-mail: maria.tkocz@us.edu.pl (Maria Tkocz)

arekheder1987@gmail.com (Arkadiusz Heder) 